\title{
Fatty acid profile and solid fat content of Peruvian cacao for optimal production of trade chocolate
}

\section{Composicion de acidos grasos y contenido de solidos grasos de cacao peruano para la produccion de chocolate óptimo}

\begin{abstract}
Using technical procedures, the fatty acid (FA) profile and solid fat content (SFC) of the Peruvian cultivar cacao beans CCN 51 and ICS 6 and the "optimal chocolate", obtained from the mixture of the first two, were determined to assess their quality. These cacao beans were found to have important nutritional values. The FA profile of the cacao beans were similar ( $p>0.05$ ); however, in the FA profile, the 'optimal chocolate' had significant differences $(p \leq 0.05)$ in terms of palmitic, arachidic and linolenic acid. The n6:n3 ratio for "optimal chocolate" was 12.0 \pm 1.7. Cacao beans had the same SFC, and SFC was highly temperature dependent, as determined using a mathematical model for chocolate. The SFC of chocolate refers to hard cacao butter content at temperatures between 20 and $25^{\circ} \mathrm{C}$, and solid fat was heat resistant from 25 to $30^{\circ} \mathrm{C}$, which is considered valuable in trade chocolate production. The quality-related properties of these lipid fractions imparted nutritional and physical aspects to the optimal dark chocolate for human consumption.

Key words: Cacao; Cacao butter; Cocoa powder; Nutritional value; Polyunsaturated fatty acid; Unsaturated fatty acid.
\end{abstract}

\section{RESUMEN}

La composición de ácidos grasos (CAG) y el contenido de sólidos grasos (CSG), de la fracción lipídica de los cultivares peruanos de cacao CCN 51 e ICS 6 así como del "chocolate óptimo", obtenido de las mezclas de las primeras dos, fueron determinados por técnicas analíticas para conocer su calidad. Estas variedades tuvieron valores nutricionales importantes. La CAG de los granos de cacao fueron similares, sin embargo la CAG del "Chocolate óptimo" tuvo diferencias significativas $(p<0,05)$ para los acidos grasos palmitico, araquidico y linoleico. El ratio n6:n3 fue de 12,0 $\pm 1,7$. El CSG de los granos de cacao fueron los mismos y tuvo una fuerte dependencia con la temperatura, también se definió un modelo matematico para el chocolate. El CSG le confiere al chocolate una consistencia dura a temperaturas de 20 a $25^{\circ} \mathrm{C}$ y resistentes al calor de 25 a $30^{\circ} \mathrm{C}$, siendo tales propiedades una ventaja en la comercialización de chocolates. La calidad de estas fracciones lipidicas tuvieron
Gabriela Cristina Chire-Fajardo ${ }^{1 *}$, Milber Oswaldo Ureña-Peralta ${ }^{1}$, Richard W. Hartel2 ${ }^{2}$

\footnotetext{
1. Departamento de Ingeniería de Alimentos, Facultad de Industrias Alimentarias, Universidad Nacional Agraria La Molina, Lima, Perú. 2. Food Science Department, University of Wisconsin-Madison, Madison, Wisonsin, U.S.A
}

*Dirigir correspondencia: Gabriela Chire. Departamento de Ingeniería de Alimentos. Facultad de Industrias Alimentarias. Universidad Nacional Agraria La Molina. Av. La Molina s/n., Lima 12, Perú. Teléfono: 6147800. Anexo 246. Email: gchire@lamolina.edu.pe

Este trabajo fue recibido el 27 de diciembre de 2018. Aceptado con modificaciones: 28 de mayo de 2019. Aceptado para ser publicado: 01 de agosto de 2019.

aspectos nutricionales y fisicos en el chocolate oscuro para consumo humano.

Palabras clave: Ácido graso insaturado; Ácido graso poliinsaturado; Cacao; Cocoa en polvo; Manteca de cacao; Valor nutricional.

\section{INTRODUCTION}

Cacao beans are obtained from cacao pods, the fruit of the cacao tree (Theobroma cacao L.) which grows in all tropical zones of Peru. Cacao butter, constituting 50\%-57\% of a dry cacao bean, is an important part of the bean owing to its various physical, chemical and sensorial properties .

Identifying the type and quantity of fatty acids (FAs) in cacao butter through research and development laboratories 
and in the processing and quality control units of manufacturing companies is imperative ${ }^{2}$. Cacao beans obtained from Ayacucho and Cusco were processed and mixed (50:50) to produce cacao liquor (cacao paste) as a raw material for bitter drinking chocolate production ${ }^{3}$; the improved product had a FA profile of palmitic $(27.70 \%)$, stearic $(30.70 \%)$, oleic $(35.90 \%)$ and linoleic $(3.50 \%)$ acids with lower presence of other FAs. Similarly, fat content in cacao beans from Ecuador and Ghana is $43.45 \%$ and $41.93 \%$, respectively ${ }^{4}$.

Torres-Moreno et al. ${ }^{2}$ quantified the FAs in unroasted cacao beans from Ecuador and Ghana and found them to contain palmitic $(27.61 \%$ and $25.01 \%)$, stearic $(33.76 \%$ and $36.40 \%)$, oleic ( $34.73 \%$ and $34.31 \%)$ and linoleic $(2.43 \%$ and $2.02 \%$ ) acids, respectively, with a lower presence of other FAs, suggesting that FA profiles vary with geographical origin. For all samples, C16:0, C18:0, C18:1 and C18:2 were the most quantitatively important FAs. Ecuadorian chocolate showed a healthier FA profile, owing to its high unsaturated FA (UFA) and low saturated FA (SAFA) ratios compared with those of Ghanaian chocolate. Additionally, Ecuadorian chocolate is an important source of stearic FA with a neutral effect on human health ${ }^{2}$.

Solid fat content (SFC) is a parameter that expresses the solid to liquid mass ratio of fat at different temperatures. The SFC affects physical properties such as consistency, stability and some important sensory attributes such as flavor, aroma and overall acceptability ${ }^{5}$. The SFC from $20^{\circ} \mathrm{C}$ to $25^{\circ} \mathrm{C}$ qualifies the hardness of cacao butter. The range of temperatures wherein decrease in the SFC is evident represents resistance to heat, whereas rapid fusion from $32^{\circ} \mathrm{C}$ to $35^{\circ} \mathrm{C}$ is responsible for cooling and a creamy sensation during tasting. To evaluate the quality of cacao butter, an important and practical parameter used in the industry is the difference between the $\mathrm{SFC}$ at $25^{\circ} \mathrm{C}$ and $35^{\circ} \mathrm{C}$ (i.e. $\Delta$ S). The presence of solid fat at a temperature below $35^{\circ} \mathrm{C}$ is recognised as a waxy sensation, which is easily detected during tasting 5 .

Apart from providing sweetness, chocolate offers positive health benefits that should be further investigated ${ }^{6}$. This study aimed to determine the FA profiles, ratios related to healthy nutrition and SFC of two Peruvian cacao cultivars CCN-51 and ICS-6 and the "optimal chocolate".

\section{MATERIALS AND METHODS}

This research was conducted at a processing plant in Chocomuseo (Lima, Peru) for cacao beans, Cacao Valley (Lima, Peru) for optimal chocolate production and University of Wisconsin-Madison (Madison, Wisconsin, USA) for the analysis of lipid fraction and determination of physical properties.

\section{Analytical methods}

Proximate analysis: The basic chemical composition i.e. moisture, ash, proteins and total fat of unroasted cacao beans and the "optimal chocolate" was analysed in triplicate following the AOAC method for cacao beans and their products? Additionally, cacao paste from the beans was analysed in triplicate for moisture and fat composition?
Caloric content was calculated by proximal analysis ${ }^{8}$ expressed in calories per 100 grams of product.

Determination of FAs: The lipid fractions of the cacao and "optimal chocolate" pastes were extracted'. Subsequently, using the ISO $12966-1^{9}$ methodology, we prepared methyl esters of $\mathrm{FAs}^{10}$. The results are reported as a relative percentage of total FA for the cacao and chocolate pastes.

Determination of SFC: We used the IUPAC Method $2.150 \mathrm{~b}^{11}$ with nuclear magnetic resonance to determine SFC. Lipid fraction of the cacao and "optimal chocolate"pastes were extracted with petroleum ether solvent; the fraction was melted, homogenised and filtered, and $2 \mathrm{~mL}$ solutions were measured in test tube at $80^{\circ} \mathrm{C}$ for $30 \mathrm{~min}$. The samples were then placed in a water bath maintained at $0^{\circ} \mathrm{C}$ for $90 \pm 5 \mathrm{~min}$, passed to a bath maintained at $26^{\circ} \mathrm{C}$ for $40 \pm 0.5 \mathrm{~h}$, placed in a bath maintained at $0^{\circ} \mathrm{C}$ for $90 \pm 5 \mathrm{~min}$ and, finally, passed to a bath maintained at the following temperatures for $60 \mathrm{~min}$ : $0^{\circ} \mathrm{C}, 5^{\circ} \mathrm{C}, 10^{\circ} \mathrm{C}, 15^{\circ} \mathrm{C}, 20^{\circ} \mathrm{C}, 25^{\circ} \mathrm{C}, 30^{\circ} \mathrm{C}, 35^{\circ} \mathrm{C}$ and $40^{\circ} \mathrm{C}$.

\section{Experimental methodology}

At a processing plant, CCN 51 (Colección Castro Naranjal) and ICS 6 (Imperial Collage Selection, District of Uchiza, Peru) were processed (roasted, peeled and ground) to obtain cacao paste. The paste samples with their replicates were evaluated and lipid fractions were extracted to evaluate FA profile. Subsequently, nine different samples of chocolate with two replicates were derived from the mixtures of cacao beans (ICS-6:CCN-51 ratios of 1:9, 5:5, and 9:1) and three dark chocolate formulations $(60 \%, 70 \%$ and $80 \%$ cacao) were processed under the same traditional processing conditions. In addition, physical properties for chocolate production were evaluated (University of Wisconsin-Madison, USA) to determine the "optimal chocolate"12.

Using the surface response method, chocolate was obtained using the mixture with desired physical properties. For validation, the "optimal chocolate" (ICS 6:CCN 51 ratio of 1:9 and $70 \%$ cacao) was manufactured again. Fat of the "optimal chocolate" was extracted to evaluate FA profile, calculate the $\mathrm{S} / \mathrm{U}$ and $\mathrm{n} 6: \mathrm{n} 3$ ratios and to determine SFC (University of Wisconsin-Madison, USA).

\section{Statistical analysis}

Experimental values obtained for each evaluated variable (FA, SFC, SAFA, MUFA, PUFA, fat, protein, ash, moisture, crude fibre) were expressed as mean \pm standard deviation. The differences of these values between CCN 51, ICS 6 and optimal chocolate were determined by analysis of variance $(p \leq 0.05)$ and Student-t test for moisture and fat content of cacao paste obtained from CCN 51 and ICS 6. A simple regression method was applied to investigate the relationship between SFC profile and temperature. All statistical analyses were performed using the STATGRAPHICS Plus ${ }^{\circledR}$ programme.

\section{RESULTS}

The proximal chemical composition of cacao beans (Table 1) showed a fat content of $43.6 \% \pm 0.12 \%$ and $45.8 \%$ 
$\pm 0.05 \%$ for CCN 51 and ICS 6, respectively. In paste, a fat content of $49.35 \% \pm 0.30 \%$ and $52.50 \% \pm 0.11 \%$ on a wet basis was observed and 50.43\% $\pm 0.31 \%$ and $53.01 \% \pm 0.11 \%$ fat content on a dry basis, respectively. Lastly, the proximal analysis of the 'optimal chocolate' paste (CCN 51:ICS 6 ratio of $1: 9,70 \%$ cacao) defined on a wet basis showed a moisture and fat content of $1.60 \% \pm 0.22 \%$ and $34.56 \% \pm 0.03 \%$ (Table 1) and a fat content on a dry basis of $35.11 \% \pm 0.03 \%$; this helped in determining the integral lipid fraction of the FA profile. The FA profile and SFC of the cacao butter from the cacao beans and "optimal chocolate" are shown in table 2 and table 3. Values were expressed at $100 \%$ of the lipid composition to compare the values of FA among the countries in South America and globally and shows the ratios of S/U and n6:n3 for the "optimal chocolate". The SFC models of cacao butter from the cacao beans and 'optimal chocolate' are shown in figure 1.

Table 1. Proximal analysis (g/100g): calories (Cal/100g) in cacao beans and paste, i.e. CCN 51, ICS 6 and the "optimal chocolate"

\begin{tabular}{|lccc|}
\hline Components & CCN 51 & Cacao beans & Optimal chocolate \\
\hline Moisture & $6.7 \pm 0.1 \mathrm{~b}$ & $6.8 \pm 0.1 \mathrm{c}$ & $1.6 \pm 0.0 \mathrm{a}$ \\
Fat & $43.6 \pm 0.1 \mathrm{~b}$ & $45.8 \pm 0.1 \mathrm{c}$ & $34.6 \pm 0.0 \mathrm{a}$ \\
Protein & $13.7 \pm 0.3 \mathrm{c}$ & $12.6 \pm 0.1 \mathrm{~b}$ & $11.7 \pm 0.0 \mathrm{a}$ \\
Ash & $3.0 \pm 0.0 \mathrm{~b}$ & $3.3 \pm 0.0 \mathrm{c}$ & $2.6 \pm 0.0 \mathrm{a}$ \\
Crude fibre & $5.4 \pm 0.0 \mathrm{c}$ & $4.5 \pm 0.0 \mathrm{~b}$ & $3.6 \pm 0.0 \mathrm{a}$ \\
Carbohydrate & $33.0 \pm 0.1 \mathrm{~b}$ & $31.5 \pm 0.0 \mathrm{a}$ & $555.9 \mathrm{a}$ \\
Calorias & $579.2 \mathrm{~b}$ & $588.8 \mathrm{c}$ & \\
& & & \\
Components & Cacao pastes & \\
\hline Moisture & $\mathbf{2 C N} \mathbf{5 1}$ & $1.0 \pm 0.0 \mathrm{~b}$ & \\
Fat, wb & $2.2 \pm 0.0 \mathrm{a}$ & $52.5 \pm 0.1 \mathrm{~b}$ & \\
Fat, db & $49.4 \pm 0.3 \mathrm{a}$ & $53.0 \pm 0.1 \mathrm{~b}$ & \\
\hline
\end{tabular}

Values are expressed as mean \pm standard deviation $(n=3)$. Different letters in the same row indicates significant differences $(p \leq 0.05)$ from low to high in alphabetical order.

Table 2. Fatty acid profile of the cacao butter obtained from CCN 51, ICS 6 and the "optimal chocolate"

\begin{tabular}{|lccc|}
\hline Fatty acid profile & $\begin{array}{c}\text { CCN 51 } \\
\mathbf{( g / 1 0 0 g})\end{array}$ & $\begin{array}{c}\text { ICS 6 } \\
\mathbf{( g / 1 0 0 g})\end{array}$ & $\begin{array}{c}\text { Optimal chocolate } \\
\mathbf{( g / 1 0 0 g})\end{array}$ \\
\hline C16:0 Palmitic acid & $29.3 \pm 0.1 \mathrm{~b}$ & $28.0 \pm 0.3 \mathrm{ab}$ & $26.6 \pm 0.7 \mathrm{a}$ \\
C18:0 Stearic acid & $32.8 \pm 0.4 \mathrm{a}$ & $33.9 \pm 0.3 \mathrm{a}$ & $33.3 \pm 1.9 \mathrm{a}$ \\
C18:1 n9c Oleic acid & $32.3 \pm 0.0 \mathrm{a}$ & $32.6 \pm 0.4 \mathrm{a}$ & $32.6 \pm 1.0 \mathrm{a}$ \\
C18:2 n6c Linoleic acid & $2.9 \pm 0.1 \mathrm{a}$ & $3.1 \pm 0.3 \mathrm{a}$ & $4.0 \pm 0.9 \mathrm{a}$ \\
C20:0 Arachidic acid & $1.1 \pm 0.0 \mathrm{a}$ & $1.1 \pm 0.1 \mathrm{a}$ & $1.3 \pm 0.1 \mathrm{~b}$ \\
C18:3 n3 Linolenic acid & $0.2 \pm 0.0 \mathrm{a}$ & $0.2 \pm 0.1 \mathrm{a}$ & $0.3 \pm 0.1 \mathrm{~b}$ \\
Saturated (SAFA) & $63.8 \pm 0.3 \mathrm{a}$ & $63.7 \pm 0.7 \mathrm{a}$ & $61.9 \pm 1.0 \mathrm{a}$ \\
Monounsaturated (MUFA) & $32.5 \pm 0.0 \mathrm{a}$ & $32.9 \pm 0.4 \mathrm{a}$ & $32.8 \pm 0.9 \mathrm{a}$ \\
Polyunsaturated (PUFA) & $3.4 \pm 0.5 \mathrm{a}$ & $3.3 \pm 0.4 \mathrm{a}$ & $4.4 \pm 1.0 \mathrm{a}$ \\
Unsaturated (UFA = MUFA + PUFA) & $35.9 \pm 0.5 \mathrm{a}$ & $36.2 \pm 0.8 \mathrm{a}$ & $37.2 \pm 0.1 \mathrm{a}$ \\
Ratio S/U & $1.78 \pm 0.03 \mathrm{a}$ & $1.76 \pm 0.06 \mathrm{a}$ & $1.67 \pm 0.03 \mathrm{a}$ \\
n6:n3 ratio & $15.7 \pm 0.6 \mathrm{~b}$ & $16.9 \pm 3.0 \mathrm{~b}$ & $12.0 \pm 1.7 \mathrm{a}$ \\
\hline
\end{tabular}

Values are expressed as mean \pm standard deviation $(n=2)$. Different letters in the same row indicate significant differences $(p \leq 0.05)$ from low to high in alphabetical order. 
Table 3. Solid fat content of the cacao butter obtained from CCN 51, ICS 6 and the "optimal chocolate".

\begin{tabular}{|cccc|}
\hline $\begin{array}{c}\text { Temperature } \\
\left({ }^{\circ} \mathbf{C}\right)\end{array}$ & $\begin{array}{c}\text { CCN 51 } \\
\mathbf{( g / 1 0 0 g})\end{array}$ & $\begin{array}{c}\text { ICS 6 } \\
(\mathbf{g} / \mathbf{1 0 0 g})\end{array}$ & $\begin{array}{c}\text { Optimal chocolate } \\
\mathbf{( g / 1 0 0 g})\end{array}$ \\
\hline 0 & $90.0 \pm 1.0 \mathrm{a}$ & $89.1 \pm 0.4 \mathrm{a}$ & $89.8 \pm 0.3 \mathrm{a}$ \\
5 & $88.4 \pm 0.1 \mathrm{a}$ & $88.3 \pm 0.2 \mathrm{a}$ & $88.3 \pm 0.3 \mathrm{a}$ \\
10 & $86.0 \pm 0.1 \mathrm{~b}$ & $85.5 \pm 0.4 \mathrm{~b}$ & $83.6 \pm 0.5 \mathrm{a}$ \\
15 & $79.7 \pm 0.4 \mathrm{a}$ & $78.6 \pm 1.4 \mathrm{a}$ & $78.3 \pm 1.2 \mathrm{a}$ \\
20 & $75.4 \pm 0.3 \mathrm{a}$ & $75.4 \pm 0.2 \mathrm{a}$ & $75.1 \pm 0.8 \mathrm{a}$ \\
25 & $67.0 \pm 0.3 \mathrm{a}$ & $67.6 \pm 0.2 \mathrm{a}$ & $69.1 \pm 1.0 \mathrm{~b}$ \\
30 & $46.6 \pm 1.1 \mathrm{a}$ & $49.8 \pm 0.5 \mathrm{~b}$ & $35.4 \pm 0.9 \mathrm{c}$ \\
35 & $2.0 \pm 0.4 \mathrm{a}$ & $2.1 \pm 0.2 \mathrm{~b}$ & $1.2 \pm 0.3 \mathrm{c}$ \\
40 & $1.4 \pm 0.3 \mathrm{a}$ & $1.7 \pm 0.1 \mathrm{a}$ & \\
\hline
\end{tabular}

Values are expressed as mean \pm standard deviation $(n=3)$. Different letters in the same row indicate significant differences $(p \leq 0.05)$ from low to high in alphabetical order.

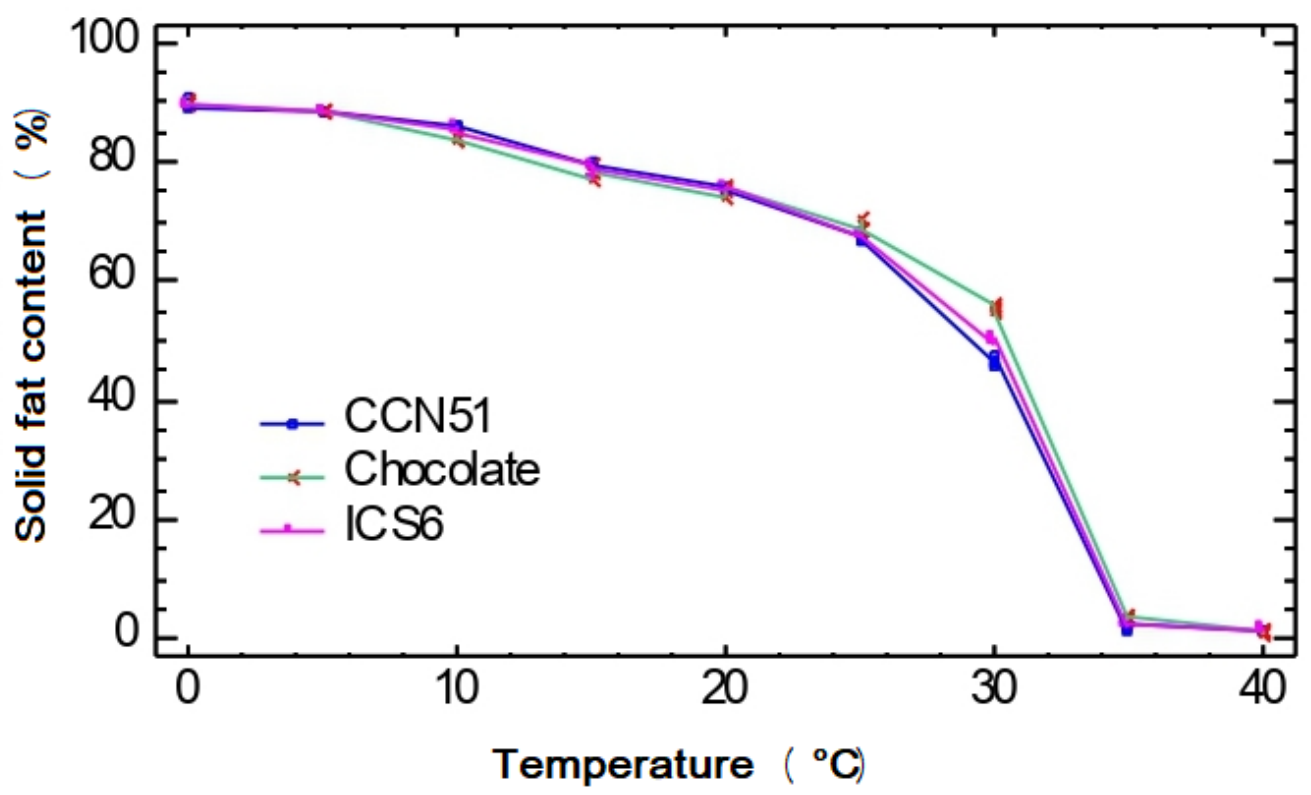

$S F C_{C N N 1}=\sqrt{7813.1-5.6 x T^{2}} S F C_{1 C S 6}=\sqrt{7744.2-5.4 x T^{2}} S F C_{\text {Qtind droolde }}=\sqrt{7730.1-5.3 x T^{2}}$

Figure 1: Model of the solid fat content (SFC) of cacao butter in terms of temperature for CCN 51, ICS 6 and the 'optimal chocolate (average of three measurements)

\section{DISCUSSION}

The FA profiles of cacao butter from the CCN 51 and ICS 6 varieties were similar ( $p>0.05)$, suggesting an advantage while preparing mixtures in chocolate producing industries.
Notably, the SAFA content $(63.80 \% \pm 0.27 \%$ and $63.65 \%$ $\pm 0.69 \%$, respectively) was higher than the UFA content $(35.93 \% \pm 0.51 \%$ and $36.19 \% \pm 0.81 \%$, respectively). Regarding stearic FA (C18:0), a neutral saturated FA type², 
we found the values of $32.77 \% \pm 0.35 \%$ and $33.87 \% \pm$ $0.31 \%$, respectively, similar to those reported for Colombian varieties $\left(31.9 \%-36.6 \%{ }^{13}\right)$.

The SAFA content of cacao butter from the African countries are as follows: Ghana, $63.24 \% \pm 0.63 \%{ }^{2}$; Ivory Coast (samples B and D, the sum of palmitic and stearic FAs), $62.1 \% \pm 0.1 \%$ and $62.9 \% \pm 0.35 \%{ }^{14}$ and West Africa, $63.8 \% \pm 0.0 \%^{15}$. The SAFA content from Asian producers are as follows: Indonesia, $63.4 \% \pm 0.45 \%$ and Malaysia, $62.8 \% \pm 0.05 \%{ }^{14}$. On the other hand, the SAFA content from South American producers are as follows: Ecuador, $62.28 \% \pm 0.57 \%{ }^{2}$ and Brazil (samples I and P), $59.4 \% \pm$ $0.60 \%$ and $57.8 \% \pm 0.20 \%$, respectively ${ }^{14}$.

The PUFA content of the Peruvian varieties, CCN 51 and ICS $6(3.39 \% \pm 0.48 \%$ and $3.29 \% \pm 0.39 \%$, respectively) was higher than that of West Africa $\left(3.1 \% \pm 0.0 \%{ }^{15}\right)$ and of Ghana and Ecuador $(2.15 \% \pm 0.07 \%$ and $2.57 \% \pm 0.25 \%$, respectively ${ }^{2}$ ), suggesting a comparative advantage in terms of nutritional value.

The S/U ratios (ratio of saturated FA to unsaturated FA) for CCN 51 and ICS 6 were similar between the two varieties $(p>0.05)$, with the values of $1.78 \pm 0.03$ and 1.76 \pm 0.06 , respectively, whereas the ratios for the varieties found in Ghana and Ecuador is $1.72 \pm 0.05$ and $1.65 \pm 0.04$, respectively ${ }^{2}$ indicating that the SAFA content is higher than the UFA content. Notably, the S/U ratio for the beans found in Ecuador is the lowest of all. Perea et al. ${ }^{13}$ report that a high S/U ratio classifies butter as hard, which is desired by the food industry. In this study, the CCN 51 and ICS 6 varieties obtained remarkably higher $\mathrm{S} / \mathrm{U}$ values.

The lipid fraction of the "optimal chocolate" was $34.56 \%$ (Table 1). In previous reports, Mursu et al. ${ }^{16}$ used dark chocolate with $33.00 \%$, Salinas and Bolivar ${ }^{17}$ used bar-type chocolate (drinking) with $37.00 \%$ fat and Chire et al. ${ }^{18}$ used dark chocolate with $36.11 \%$ fat. Because the 'optimal chocolate' had a high fat and energy content $(34.56 \%)$, daily consumption should be regulated to $25 \mathrm{~g} /$ $\mathrm{d}^{16,2}$. In terms of fat content $(35.11 \% \pm 0.03 \%$, dry basis), the FA profile of the "optimal chocolate" was determined. While the SAFA content of the "optimal chocolate" was $61.90 \% \pm 1.01 \%$ that of the chocolate prepared with the cacao beans from Ghana and Ecuador is $66.03 \% \pm 2.09 \%$ and $63.95 \% \pm 1.39 \%$, respectively ${ }^{2}$, and that of the bartype chocolate (drinking) reaches $63.5 \%{ }^{17}$. For the "optimal chocolate", the stearic FA content (C18:0) was $33.34 \% \pm$ $1.93 \%$ representing one third of the fat content. Stearic FA increases high density lipoprotein cholesterol and serum triglyceride levels in blood $^{2}$. PUFAs were present in high contents in the "optimal chocolate" $(4.36 \% \pm 1.01 \%)$ compared with those in the dark chocolates from Ghana and Ecuador $\left(1.78 \% \pm 0.48 \%\right.$ and $2.36 \% \pm 0.59 \%$, respectively ${ }^{2} ; 2.45$ and 1.85 fold more, respectively).

As per previous studies, dark chocolate traded in Finland has $3.03 \%$ linoleic and linolenic FAs $^{16}$, bar-type chocolate (drinking) from Venezuela has $3.16 \%{ }^{17}$ and the "optimal chocolate" from Peru (this study) had $4.35 \%$. The
$\mathrm{S} / \mathrm{U}$ ratio is a health indicator for chocolate with standard fat content: the S/U ratio for 'optimal chocolate' reached $1.67 \% \pm 0.03 \%$, almost similar to that of bar-type chocolate $\left(1.75 \%{ }^{17}\right)$. In the study by Torres-Moreno et al. ${ }^{2}$, the S/U ratios for chocolates from Ecuador and Ghana are $1.77 \pm$ 0.01 and $1.94 \pm 0.06$, respectively, which increase during cocoa bean processing and chocolate production, with inverse effects on the results of the present study, because the $\mathrm{S} / \mathrm{U}$ ratios for cacao beans $(1.78 \pm 0.03$ and $1.76 \pm 0.06)$ decreased to obtain the "optimal chocolate" $(1.67 \pm 0.03)$.

In addition, essential FAs (omega 6 and omega 3 ) produce metabolites that exert positive and negative effects on health and if the omega 6:omega 3 ratio is higher, the product is injurious to health ${ }^{19}$. The "optimal chocolate" had $4.35 \%$ of omega 6 and omega $3^{2}$, whereas as chocolate from Ecuador has $2.30 \%$ and chocolate from Ghana has $1.80 \%$. Per Mursu et. al. ${ }^{16}$, chocolate traded in Finland has $1.00 \%$ of omega 6 and omega 3. Thus, our results indicate a good presence of essential FAs in the chocolate. Because the ratio of omega 6:omega 3 (Table 2) for "optimal chocolate" was $12.0 \pm 1.7$, a daily diet must be supplemented with food products that help attain a ratio of essential FA of $5: 1^{19}$. Chocolate from Ecuador has 21.6, 10.5 from Ghana and 9.0 ${ }^{16}$ from Finland. Thus, our results of 12.0 was near the ratio from Ghana. This could be due to the origin or processing factors. Curti et al. ${ }^{20}$ studied the debittering process of Lupinus species and show an omega 6:omega 3 ratio from $10.3 \pm 0.3$ to $8.8 \pm$ 0.6 . According to Mataix ${ }^{21}$, the FA content in $100 \mathrm{~g}$ of food comprising various fruits and nuts, i.e. almonds, peanuts, walnuts and "sacha inchi" seeds ${ }^{22}$, has omega 6:omega 3 ratios of $37.78,36.43,5.26$ and 0.48 , respectively, indicating that only walnuts possess a balanced value.

We compared three treatments (CCN 51 cacao, ICS 6 cacao and "optimal chocolate") in terms of FA profile. In terms of palmitic FA, we found significant differences among the treatments $(p \leq 0.05)$. The "optimal chocolate", which contained $90 \%$ of ICS 6 and $10 \%$ of CCN 51 cacao, showed similar palmitic FA content as that of ICS 6 cacao fat owing to its higher composition. On the other hand, stearic FA content was similar in all treatments ( $p>0.05$ ), with $32.77 \% \pm 0.35 \%, 33.87 \% \pm 0.31 \%$ and $33.34 \% \pm 1.93 \%$ in the CCN 51 cacao, ICS 6 cacao and "optimal chocolate", respectively. Overall, stearic FA content was approximately one third of the total fat content. Oleic FA $(32.30 \% \pm 0.00 \%$, $32.59 \% \pm 0.36 \%$ and $32.55 \% \pm 0.97 \%$, respectively) was the second highest FA and was similar among all treatments ( $p>0.05)$, followed by linoleic FA $(2.94 \% \pm 0.09 \%, 3.10 \%$ $\pm 0.33 \%$ and $4.01 \% \pm 0.89 \%$, respectively), with similar results among all treatments. Lastly, minimal amounts of arachidic and linolenic FAs were found with significant differences $(p \leq 0.05)$ among the treatments.

It is recommended to characterize cocoa butter of other varieties and countries and differentiate them by zones. Innovative processes should be developed to improve the nutritional indicators of cocoa lipids.

The SFC of the lipid fractions of the CCN 51 cacao, 
ICS 6 cacao and the "optimal chocolate" (Table 3) from $0^{\circ} \mathrm{C}$ to $40^{\circ} \mathrm{C}$ with intervals of $5^{\circ} \mathrm{C}$ showed that the curves decreased and were characteristic of cacao. CCN 51, ICS 6 and the "optimal chocolate", presented no significant differences in terms of SFC.

Using the same method as used in the present study (IUPAC method 2.150b), Wennermark et al. ${ }^{23}$ report the SFC of cacao butter with values of $82 \%$ at $10^{\circ} \mathrm{C}, 78 \%$ at $20^{\circ} \mathrm{C}, 70 \%$ at $25^{\circ} \mathrm{C}, 50 \%$ at $30^{\circ} \mathrm{C}$ and $>1 \%$ at $35^{\circ} \mathrm{C}$. Additionally, they found the differences among the cacao butter contents of different origins (Malaysia, West Africa and Brazil), with Brazilian beans showing the lowest SFC in the temperature range of $10^{\circ} \mathrm{C}-30^{\circ} \mathrm{C}$. Chire and Córdova ${ }^{3}$ reported different SFC values since the cacao butter was a mixture of different cacao beans $50 \%$ Ayacucho and $50 \%$ Cusco) from the southern part of Peru, with $88.10 \%$ at $10^{\circ} \mathrm{C}, 61.10 \%$ at $20^{\circ} \mathrm{C}, 17.50 \%$ at $25^{\circ} \mathrm{C}, 1.00 \%$ at $30^{\circ} \mathrm{C}$, $0.30 \%$ at $35^{\circ} \mathrm{C}$ and $0.30 \%$ at $37^{\circ} \mathrm{C}$. This indicates that the solid fat of cacao butter under study had greater hardness in the temperature range of $0^{\circ} \mathrm{C}-25^{\circ} \mathrm{C}$, which further acquired additional heat resistance at $25^{\circ} \mathrm{C}-30^{\circ} \mathrm{C}$ and, finally, became more waxy at $35^{\circ} \mathrm{C}-40^{\circ} \mathrm{C}$ than butter from the southern part of the country ${ }^{24}$.

For cacao butter from Vietnam ${ }^{25}$, the SFC values range from $83.70 \% \pm 0.20 \%$ to $86.40 \% \pm 0.30 \%$ at $10{ }^{\circ} \mathrm{C}, 73.30 \%$ $\pm 0.20 \%$ to $76.20 \% \pm 0.40 \%$ at $20{ }^{\circ} \mathrm{C}, 63.80 \% \pm 0.20 \%$ to $68.90 \% \pm 0.30 \%$ at $25^{\circ} \mathrm{C}, 36.70 \% \pm 0.5 \%$ to $43.60 \%$ $\pm 0.60 \%$ at $30{ }^{\circ} \mathrm{C}$ and $0.6 \% \pm 0.40 \%$ to $1.80 \% \pm 0.30 \%$ at $35^{\circ} \mathrm{C}$. Their results are similar to those of the present study at temperatures below $20^{\circ} \mathrm{C}$ (hard butter) and at temperatures between $20^{\circ} \mathrm{C}$ and $25^{\circ} \mathrm{C}$ for heat resistant cacao butter. However, the cacao butter from Vietnam acquire lower SFC values at temperatures above $30^{\circ} \mathrm{C}$, suggesting that the cacao butter of the varieties under study had waxy residues.

Similarly, for a type of cacao butter from Ghana, Tran et al. ${ }^{25}$ report a SFC of $85.90 \% \pm 0.20 \%$ at $10^{\circ} \mathrm{C}, 74.60 \%$ $\pm 0.20 \%$ at $20^{\circ} \mathrm{C}, 65.30 \% \pm 0.30 \%$ at $25^{\circ} \mathrm{C}, 40.30 \% \pm$ $0.50 \%$ at $30^{\circ} \mathrm{C}$ and $0.70 \% \pm 0.20 \%$ at $35^{\circ} \mathrm{C}$, which are similar to the results of the present study at temperatures of $<20^{\circ} \mathrm{C}$. However, at temperatures of $25^{\circ} \mathrm{C}$, the SFC was higher in our study, confirming the heat resistance of cacao butter. In the $\triangle \mathrm{S}$ experiment, the SFC values in CCN 51, ICS 6 and the "optimal chocolate" were $65.01 \%$, 65.52\% and $65.34 \%$, respectively, which were within the study range reported by Tran et al.25 In the last section of the SFC curve (temperatures of $35^{\circ} \mathrm{C}-40^{\circ} \mathrm{C}$ ), the butter in the present study had waxy residues, more than that of the varieties from Vietnam and Ghana ${ }^{25}$.

Remarkably, CCN 51, ICS 6 and the "optimal chocolate" presented an inverse relationship between their SFC and temperature $(\mathrm{R} 2=96.61 \%, 96.81 \%$ and $96.55 \%$ respectively), which are empirical models based on observation and experimentation ${ }^{26}$. Data were analysed by simple regression, where the dependent variable was SFC and the independent variable was temperature and the model was double square. The mathematical models for the butter (lipid fraction) obtained for CCN 51, ICS 6 and the "optimal chocolate" (Figure 1) had negative slopes and were quadratic.

The results showed that the SFC presents a hard cacao butter, resistant to heat and with serosity residues. Therefore, to characterize the SFC of the cacao butter a mathematical model that can confirm the quality of the cacao butter is recommended. For example, for the products with cocoa butter replacers or substitutes, the SFC should be different.

\section{CONCLUSIONS}

The FA profiles of the Peruvian cacao varieties CCN 51 and ICS 6 from the district of Uchiza (Peru) showed nutritional potential in terms of PUFA content $(3.39 \% \pm$ $0,48 \%$ and $3.29 \% \pm 0.39 \%$, respectively) that was higher than that of the African varieties. Thus, the Peruvian varieties provide a greater nutritional contribution to the "optimal chocolate" blend processed with $70 \%$ cacao and cacao bean mixes (10\% CCN 51 and 90\% ICS 6). The PUFA content of the "optimal chocolate" was $4.36 \% \pm 1.01 \%$, a level significantly higher than that of other chocolate producers in the world and those recognized in Ecuador. Similary, the 'S/U ratios' calculated for CCN 51 cacao, ICS 6 cacao and the "optimal chocolate" were $1.78 \% \pm 0.03 \%, 1.76 \% \pm$ $0.06 \%$ and $1.67 \% \pm 0.03 \%$, respectively. The $\mathrm{n} 6: \mathrm{n} 3$ ratio for the "optimal chocolate" was $12.0 \pm 1.7$, thus differentiating it from those obtained from African cacao.

The high SFC at low $10^{\circ} \mathrm{C}$ and medium $20^{\circ} \mathrm{C}$ temperatures is characteristic of hard cacao butter, and a significantly high SFC at high temperatures $\left(35^{\circ} \mathrm{C}\right.$ and $\left.40^{\circ} \mathrm{C}\right)$ is considered beneficial for the distribution of products in tropical areas because it imparts heat resistance. The SFC in terms of temperature had a negative slope formed a quadratic equation.

Acknowledgements: We thank EPG (Escuela de Posgrado) for partly funding our travel to the University of Wisconsin-Madison (USA) and OGI (Oficina de Gestión de la Investigación) for their help in correcting our scientific communications.

\section{REFERENCES}

1. Jahurul MHA, Zaidul ISM, Norulaini NAN, Sahena F, Jinap S, Azmir J, Sharif KM, Mohd Omar AK. Cocoa butter fats and possibilities of substitution in food products concerning cocoa varieties, alternative sources, extraction methods, composition and characteristics. J Food Eng 2013; 117: 467-476.

2. Torres-Moreno M, Torrescana E, Salas-Salvado J, Blanch C. Nutritional composition and fatty acids profile in cocoa beans and chocolates with different geographical origin and processing conditions. Food Chem 2015; 166: 125-132.

3. Chire G, Córdova A. Improvement of bitter chocolate for cup by using cocoa liquor. Rev Cient Invest 2005; 8: 87-91.

4. Torres-Moreno M, Tarrega A, Costell E, Blanch C. Dark chocolate acceptability: Influence of cocoa origins and processing conditions. J Sci Food Agric 2012; 92: 404-411.

5. Quast LB, Luccas, V, Ribeiro APB, Cardoso, LP, Kieckbush TG. Physical properties of tempered mixtures of cocoa butter, CBR and CBS fats. Int J Food Sci Technol 2013; 48: 1579-1588.

6. Tomas-Barberán FA, Cienfuegos-Jovellanos E, Marín A, 
Muguerza B, Gil-Izquierdo A, Cerdá B, Zafrilla P, Morillas J, Mulero J, Ibarra A, Pasamar MA, Ramon D. Espín JC. A new process to develop a cocoa powder with higher flavonoid monomer content and enhanced bioavailability in healthy humans. J Agric Food Chem 2007; 55: 3926-3935.

7. Association of Official Agricultural Chemists. Official Methods of Analysis of the AOAC International Method 920.75a. 20th ed. Volumen II. Maryland. The Association, 2016.

8. Collazos C, White PL, White HS, Viñas E, Alvistur E, Urquieta R, Vásquez J, Días C, Quiroz A, Roca A, Hegstece DM, Bradfield $R B$, Herrera $N$, Faching $A$, Robles $N$, Hernández $E$, y Arias M. Tablas Peruanas de Composición de Alimentos. Ministerio de Salud. Instituto Nacional de Salud. Centro Nacional de Alimentación y Nutrición. 7ma edición. 1996.

9. ISO 12966-1. Animal and Vegetable fats and oils. Gas chromatography of methyl esters - Part 1: guidelines on modern chromatography of fatty acid methyl esters, 2014.

10. ISO 5509. Animal and Vegetable fats and oils. Preparation of methyl esters of fatty acids, 2000.

11. IUPAC. Solid content determination in fats by NMR (lowresolution nuclear magnetic resonance), 1987, Norm version 2.150b.

12. Chire GC, Ureña MO, Garcia SM, Hartel RW. Optimización de la formulación de chocolate oscuro a partir de la mezcla de granos de cacao y contenido de cacao aplicando método de superficie de respuesta. Enfoque UTE 2019; 10(2): xyz-wsd.

13. Perea $J A$, Ramirez OL, Villamizar AR. Physicochemical characterization of regional Colombian cocoa materials. Rev Bio Agro 2011; 9: 35-42.

14. Foubert I, Vanrolleghem PA, Thas O, Dewettinck K. Influence of chemical composition on the isothermal cocoa butter crystallization. J Food Sci 2004; 69: 478-487.

15. Tran PD, Van de Walle $D$, Hinneh M, Delbaere C, De Clercq N, Tran DN. Dewettinck K. Controlling the stability of chocolates through the incorporation of soft and hard StOSt-rich fats. Eur J Lipid Sci Technol 2015; 117: 1700-1713.

16. Mursu J, Voutilainen S, Nurmi T, Rissanen TH, Virtanen J, Kaikkonen J, Nyyssonen K, Salonen J. Dark chocolate consumption increases HDL cholesterol concentration and chocolate fatty acids may inhibit lipid peroxidation in healthy humans. Free Radic Biol Med 2004; 37: 1351-1359.

17. Salinas N, Bolivar W. Fatty acids in Venezuelan chocolates and their analogues. An Venez Nutr 2012; 25: 34-41.

18. Chire GC, Valdivia RA, Orihuela CA, Ureña MO. Assessment of physical and physicochemical quality of main chocolates traded in Peru. Acta Agron 2017; 66(2): 164-171.

19. Sanhueza Catalan J, Duran Aguero S, Torres Garcia J. Dietary fatty acids and their relation to health. Nutr Hosp 2015; 32: 1362-1375.

20. Curti CA. Curti RN. Bonini N. Ramón AN. Changes in the fatty acid composition in bitter Lupinus species depend on the debittering process. Food Chem 2018; 263: 151-154.

21. Mataix Verdu, J. Food lipids. In Mataix Verdu J, Gil Hernandez A (Eds). White paper of the omega-3. Granada: Puleva Food. 2002.

22. Chirinos R, Zorrilla D, Aguilar-Galvez A, Pedreschi R, Campos $D$. Impact of roasting on fatty acid, tocopherols, phytosterols, and phenolic compounds present in Plukenetia huayllabambana Seed. Journal of Chemistry 2016; 1-10.

23. Wennermark B, Granroth B, Kruse B, Tudesjo C, Atkinson G, Bergqvist G, Malmros H, Alander J, Karlsson J, Thieme J, Johnston K, Bjornsholt K, Ingvarsson L, Hakansson M, Pedersen $M$, Persson $M$, Wennermark $M$, Johansson $M$, Hjorth $M$, Persson P, Shaw P, Miller RL, Eriksson S, Fyke T. Chocolate and Confectionery. In Nielsen K (Ed). Handbook vegetable oils and fats. Sweden. AAK Academy. 2012.

24. Torbica A. Jovanovic O. Pajin B. The advantages of solid fat content determination in cocoa butter and cocoa butter equivalents by the Karlshamns method. Eur Food Res Technol 2006; 222: 385-391.

25. Tran PD. Van Durme J. Van de Ville D. De Winne A. Delbaere C. De Clercq N. Pan TTQ. Nguyen CHP. Tran DN. Dewettinck K. Quality attributes of dark chocolate produced from Vietnamese cocoa liquors. J Food Qual 2016; 39: 311-322.

26. Dijkstra J. Forbes JM. France J. Introduction. In Mataix Dijlstra J. Forbes JM. France J. (Eds). Quantitative aspects of ruminant digestion and metabolism. Second edition. Cani Publishing. 2005. 